\title{
A GUERRA INTERMINABLE. LA CONQUISTA DEL OESTE COMO MODELO CULTURAL DE LA GUERRA CONTRA EL TERROR
}

LUIS PÉREZ OCHANDO

Doctor en Historia del Arte Luis.perez@uv.es

Resumen: El presente artículo explora la representación cultural de las guerras indias como un precedente de los planteamientos que legitimaron la guerra contra el terrorismo después del once de septiembre. Nuestro objetivo será analizar el relato cinematográfico de las guerras contra los indios como un patrón ideológico, interiorizado culturalmente, que resurge como respuesta a los nuevos conflictos. Concretamente, nos centraremos en dos aspectos fundamentales del western, la filosofía del "destino manifiesto" y la representación de la otredad, dos ideas que ayudan a explicar la respuesta de la ideología dominante a los atentados del once de septiembre.

Palabras clave: Cine / Ideología / Western / Destino manifiesto / Guerra contra el terror.

Abstract: This paper explores the cultural representation of American Indian Wars as a precedent of the arguments that legitimized the War on Terror after 9/11. Our goal will be to analyse the film narratives about the American Indian Wars as a culturally internalized ideological pattern that reemerges as a response to newer conflicts. More specifically, we will focus on two main aspects of westerns: the philosophy of Manifest Destiny and the representation of otherness, two ideas that help to explain how dominant ideology answered the 9/11 terrorist attacks.

Key words: Film / Ideology / Western / Manifest Destiny / War on Terror.

En un mundo de conflictos, en un mundo de víctimas y verdugos, la tarea de la gente pensante debe ser -como sugirió Albert Camus-, no situarse en el bando de los verdugos.

Howard Zinn, La otra historia de los Estados Unidos

En 1818, el general Andrew Jackson volvió a cruzar la frontera de La Florida española para atajar las fugas de esclavos negros que, a menudo, acababan uniéndose a los nativos seminolas. Durante esta invasión, ya de paso, el general Jackson emprendió una campaña de exterminio de indígenas y negros, incendió varias aldeas y tomó las fortificaciones españolas de San Marcos y Pensacola; ${ }^{1}$ pero, además, capturó a dos súbditos británicos que comerciaban con los indios, Robert Ambrister y Alexander George Arbuthnot. El tribunal los condenó al látigo, pero Jackson juzgó que el castigo pecaba de indulgente, así que los ejecutó: Ambrister fue fusilado; Arbuthnot, ahorcado del palo mayor de su propio barco; su crimen, ayudar a un enemigo del Estado.

Tanto la invasión de un territorio soberano con el objetivo de perseguir a los enemigos de la patria como la aplicación extralegal de la justicia o la condena de ciudadanos de otras naciones son hechos que resonarán en la Guerra contra el Terror emprendida por el gobierno de George Bush tras el 11 de septiembre. De hecho, el episodio citado volverá a la luz en 2011, pero no como denuncia de una ilegalidad militar sino, por inversión de términos, como justificación legal de la retención de Al Bahlul en la prisión de Guantánamo, duran-

\footnotetext{
* Fecha de recepción: 15 de abril de 2017 / Fecha de aceptación: 9 de julio de 2017.

1 Jackson había pedido permiso a John C. Calhoun, ministro de guerra del presidente Monroe, para conquistar Florida, pero no obtuvo respuesta. "Presumiblemente, la idea era dejar que Jackson hiciera lo que quisiera (y sabían que éste actuaría audazmente). Si las cosas salían bien, magnífico. En caso contrario, Monroe y Calhoun podían decir que Jackson había actuado sin órdenes y arrojarlo a los lobos." ASIMOV, Isaac, 1983, p. 24.
} 
te más de una década, con la acusación de haber ayudado a los terroristas. Las penas de Ambrister y Arbunthnot son un hecho histórico, pero no un precedente legal; aun así, en el informe de la acusación, el capitán de la marina Edward S. White ${ }^{2}$ lo utilizaba como excusa, afirmando:

Los seminola no sólo eran beligerantemente ilegales, sino que, al igual que la actual Al Qaeda, hacían la guerra contra objetivos estadounidenses de una manera que violaba los usos y costumbres de la guerra. Dado que Ambrister y Arbuthnot ayudaron a los seminolas a llevar a cabo una beligerancia ilegal y a violar las leyes de la Guerra, su conducta era culposa y punible. ${ }^{3}$

Las protestas de los colectivos indios no se hicieron esperar; ese mismo día, John $\mathrm{H}$. Dossett, abogado del National Congress of American Indians, se dirigió al tribunal para expresar "nuestra preocupación sobre la analogía histórica distorsionada y ofensiva utilizada por los Estados Unidos, en este caso, cuando se compara la Guerra Seminola (1817-1818) con el terrorismo de Al Qaeda". ${ }^{4} \mathrm{La}$ anécdota parece desvelar una asociación ideológica entre la manera de afrontar la actual amenaza terrorista y el relato cultural de las Guerras indias, ${ }^{5}$ sin embargo, no se trata de una relación unívoca ni transparente, sino sinuosa, compleja, discontinua. La de George W. Bush no fue la primera Guerra contra el Terror, hubo antes otras en las que los enemigos no eran terroristas talibanes sino sioux, comanches, creeks o chiricauas: en ambos casos, las ideas de civilización, guerra y enemigo presentan continuidades y coincidencias.
Las siguientes páginas exploran la representación cultural de las guerras indias como un precedente de los planteamientos que legitimaron la guerra contra el terrorismo después del once de septiembre. El western es el mito fundacional de Norteamérica, un cantar de gesta que construye la idea de la patria americana como una conquista de la tierra prometida; 6 recurrir a su relato para construir el discurso posterior al once de septiembre supone apelar a los mimbres que tejen las ideas colectivas de nación y destino, de enemigo y violencia. Nuestro objetivo será, por tanto, analizar el relato cinematográfico de las guerras contra los indios como un patrón ideológico, interiorizado culturalmente, que resurge como respuesta a los nuevos conflictos. ${ }^{7}$ Concretamente, nos centraremos en dos aspectos fundamentales del western, la filosofía del "destino manifiesto" y la representación de la otredad, dos ideas que ayudan a explicar la respuesta de la ideología dominante a los atentados del once de septiembre.

\section{Ambrister, Arbuthnot y los comancheros}

¡Maldito sea quien simpatice con los indios! He venido a matar indios, y considero justo y honorable usar todos los medios a mi alcance para lograrlo. Coronel John Chivington, 27 de noviembre de $1864 .^{8}$

Las proezas de Andrew Jackson en La Florida no fueron del agrado de la Corona española ni de la opinión pública británica, pero entusiasmaron al público estadounidense, por lo que Jackson no

\footnotetext{
2 Citado por ROSENBERG, Carol, 2011 y por TIRADO, Michelle, 2011.

3 Further, not only was the Seminole belligerency unlawful, but, much like modern-day al Qaeda, the very way in which the Seminoles waged war against U.S. targets itself violated the customs and usages of war. Because Ambrister and Arbuthnot aided the Seminoles both to carry on an unlawful belligerency and to violate the laws of war, their conduct was wrongful and punishable.

${ }^{4}$ Citado por ROSENBERG, Carol, 2011: We wish to express our significant concern at the distorted and offensive historical analogy used by the United States in this case when it compared the first 'Seminole War' of 1817-18 to the terrorism of al Qaeda.

${ }^{5}$ Otro dato que sugiere este tipo de asociaciones se detecta en el hecho de que el nombre clave para la operación de asesinato de Osama Bin Laden fuera "Geronimo" y no "Atila", "Amílcar" o cualquier otro palabro al azar.

${ }^{6}$ BALLÓ, Jordi; PÉREZ, Xavier, 1997, pp. 42-46.

7 Nuestra metodología se basa en los fundamentos teóricos y metodológicos planteados en Noche sobre América (PÉREZ OCHANDO, Luis, 2017, pp. 21-168), y consiste en el análisis de un amplio corpus de textos en busca de continuidades ideológicas y motivos recurrentes para, una vez establecidos, buscar correspondencias y discontinuidades entre estos y los discursos hegemónicos de su periodo histórico, entendidos estos últimos como la expresión de las relaciones materiales dominantes en forma de ideas. Siguiendo esta metodología, buscaremos en los textos tanto el contenido ideológico manifiesto (WAYNE, Michael, 2005, pp. 119-120) como el contenido elidido (ALTHUSSER, Louis, 1977, pp. 215-216) y, seguidamente, estableceremos conexiones entre ellos con el fin de trazar un cartografiado cognitivo (JAMESON, Fredric, 1988), es decir, una pauta interpretativa que permita al lector comprender la historia y los discursos de poder inscritos tanto en el conjunto de los textos como en cada uno de ellos. Noche sobre América aplicaba su método de análisis a una cuestión contemporánea -los cambios en los discursos hegemónicos después del once de septiembre-, por lo que contrastaba sincrónicamente las líneas ideológicas dominantes en el cine de terror con la historia política más reciente; sin embargo, dado que aquí buscaremos los antecedentes culturales de esos mismos discursos dominantes, deberemos realizar también un análisis diacrónico.

${ }^{8}$ Cit. BROWN, Dee, 2012, p. 103.
} 
fue censurado ni recriminado en modo alguno. Los asesinatos de Ambrister y Arbuthnot -amén del de incontables seminolas y negros- no sólo quedaron impunes sino que además sentaron cátedra, no en la jurisprudencia, pero sí en la literatura popular y el cine estadounidense. La condena no se dirige, por tanto, solamente al otro, sino a cualquiera que le preste auxilio o conviva con él, a cualquiera que, en definitiva, lo reconozca como interlocutor válido, ya sea para el comercio o para el diálogo.

En el western no hay personaje más despreciable que el comanchero o el que trata con indios. Como escribe Alan Le May (2013, pp. 235-236) en su novela Centauros del desierto:

Ese nombre, comanchero, era odiado por los texanos. [...] Si eras norteamericano y comerciabas con comanches en territorio estadounidense [...] se te consideraba comerciante. Pero si eras mexicano, establecido en México, y tenías tratos comerciales con los comanches en la franja suroeste de los Staked Plains, no se te consideraba comerciante, sino comanchero. [...] Mart siempre había oído que los comancheros eran una raza pervertida, escurridiza y cobarde, que vivían como alimañas rodeados de indescriptible porquería.

Puerco, maleducado, bebedor y violento, el traficante interpretado por Lee Marvin en Los comancheros (The Comancheros, Michael Curtiz, 1961) lleva trencita india y medio cráneo descuerado; en otras palabras, no le falta nada para ser una alimaña asilvestrada, alguien capaz de ganar un puñado de dólares aun a costa de la muerte de los colonos. Jake Cutter (John Wayne) y Paul Regret (Stuart Whitman) siguen la pista de los comancheros hasta dar con el enclave en que éstos viven y trafican, un agujero perdido en el desierto y regido por una autoridad cruenta (Fig. 1). Traficantes de mirada turbia vigilan la llegada de los héroes; al fondo, moribundos y cadáveres cuelgan por los

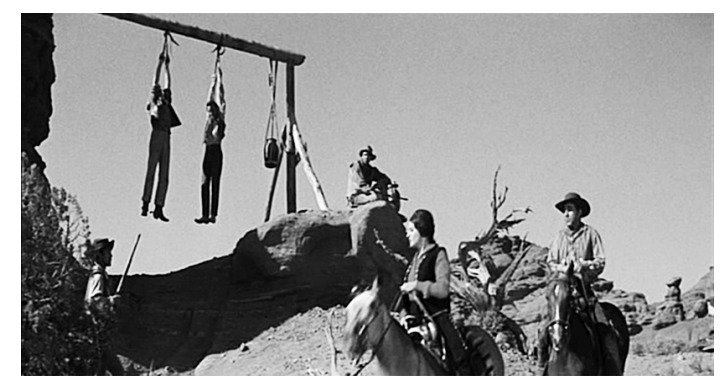

Fig. 1. Los comancheros (The Comancheros, Michael Curtiz, 1961). Un nido de traficantes.

pies o por las manos. Pero en la capital comanchera se yergue también una villa palaciega, con vajiIla y copas de oro en las que ofrecer el mejor vino al jefe Camisa de Hierro (George J. Lewis). Incluso cuando algunos comancheros puedan gozar de cierto atractivo -tal es el caso del líder de los comancheros (Nehemiah Persoff) y de su hija (Ina Balin)-, el relato ha demostrado ya con creces -en dos secuencias anteriores- el nefasto efecto que produce este comercio entre los blancos y los comanches: la masacre de los colonos. ${ }^{9}$

El crimen de quienes comerciaban con los indios no era, por supuesto, estafar a los nativos o cambalachar cuentas de vidrio por pieles y tierras; el delito tampoco estaba en denigrar las razas autóctonas con whisky, chínguere, aguardiente o matarratas; ${ }^{10}$ ni siquiera hubiera sido pecado suministrarles mantas infectadas de viruela; ${ }^{11}$ lo realmente imperdonable era vender munición y rifles a los indios en pie de guerra.

En Soldado azul (Soldier Blue, Ralph Nelson, 1970), el recluta Honus (Peter Strauss) incendia el carromato del quincallero Isaac Q. Cumber (Donald Pleasance) al descubrir que esconde rifles en un doble fondo para vendérselo a los cheyenes. Ahora bien, el objetivo de Soldado azul es darnos otro punto de vista sobre la historia del Oeste y, más concretamente, aleccionarnos sobre la masacre de Sand Creek. ${ }^{12}$

\footnotetext{
9 Se trata de un lugar común que se repite en películas como Río Conchos (Rio Conchos, Gordon Douglas, 1964).

${ }_{10}$ Aunque en Pacto de honor (The Indian Fighter, André de Toth, 1955), el jefe sioux Nube Roja (Eduard Franz) quema vivo a todo blanco que venda alcohol a los suyos y a todo indio que lo beba.

11 Entre 1994 y 2003, el historiador Ward Churchill afirmó en seis artículos que el ejército yanqui distribuyó deliberadamente mantas infectadas de viruela entre los nativos. Churchill fue acusado de falsario por BROWN, Thomas, 2006, pp. 100-127, por lo que se formó un tribunal académico que acabó fallando en su contra. Por ello, fue despedido de la Universidad de Colorado, pero apeló al Tribunal del Distrito, que le dio la razón. El veredicto quedó en papel mojado debido al estatus de "inmunidad cuasi-judicial" de dicha universidad. Noam Chomsky, Howard Zinn y otros partidarios de Churchill subrayaron que la campaña contra él podría haber estado motivada por la polémica causada por "Some People Push Back: On the Justice of Roosting Chickens", en el que Churchill interpretaba el 11-S como una consecuencia de la política exterior estadounidense y describía a las víctimas con "pequeños Eichmann".

12 En 1864, una milicia de Colorado bajo el mando del coronel John Chivington cargó contra un poblado cheyene; durante la gesta, entre setenta y ciento sesenta cheyenes, en su mayoría mujeres y niños, fueron mutilados y asesinados con una saña y una crueldad inconcebibles. Los soldados americanos arrancaron cabelleras, dedos, fetos y genitales femeninos para quedárselos como souvenir (BROWN, Dee, 2012, pp. 103-109; TAYLOR, Colin F., 1995, p. 78).
} 


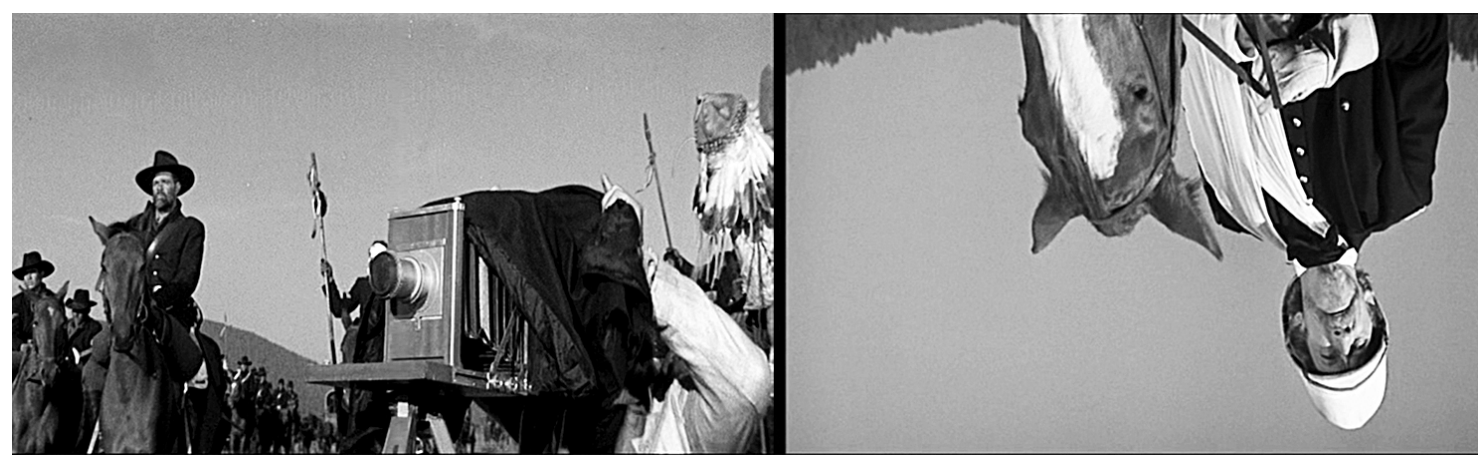

Fig. 2. Soldado azul (Soldier Blue, Ralph Nelson, 1970). La cámara invierte la imagen del coronel responsable de la masacre de Sand Creek.

El tono didáctico queda patente desde el rótulo y la canción que dan comienzo al filme: "Te voy a contar una historia real / en un lenguaje que puedas entender. / No voy a hablar como un profesor de historia", ${ }^{13}$ canta Buffie Sainte-Marie. A partir de aquí, recorremos los paisajes de Soldado azul de la mano de Honus, nuestro representante diegético, junto a quien debemos aprender que existe otro punto de vista y que privar a los indios de un suministro de armamento supone también dejarlos inermes ante el ejército.

La obsesión patriótica de Honus por prender el carromato trae la desgracia sobre sí mismo y sobre los cheyenes. Una sucesión de planos describe la masacre como una orgía de cuerpos violados, acuchillados, empalados y mutilados; los soldados danzan con brazos y piernas ensartados en sus sables en ristre. Concluye la secuencia y, por virtud de la inversión fotográfica, vemos al coronel responsable de la masacre desde el interior de la cámara, proyectado cabeza abajo, como corresponde a todos los traidores (Fig. 2). En un falso contraplano, los escasos supervivientes de la masacre escuchan las arengas del oficial junto al pueblo calcinado.

Como western revisionista y pro-indio, Soldado azul pretende centrarse en este contraplano de la historia y su registro oscila entre los tópicos familiares para el espectador y una serie de presuntas rupturas: vender armas a los indios quizá no sea tan aberrante, pero el chamarilero que comercia con ellos sigue siendo un personajillo estrafalario $y$ mezquino. A la sombra de Ambrister y Arbuthnot, cualquiera que trate favorablemente con los indios es visto como un traidor a su nación y su raza.

La idea había sido plantada casi doscientos años atrás, "si no estás con nosotros, estás contra noso- tros", y a los neoconservadores no les fue difícil cosechar sus frutos durante la Guerra contra el Terror. Irak y Afganistán no fueron atacados como causantes del atentado del World Trade Center, sino bajo la acusación de dar cobijo a los terroristas que lo causaron. La ambigüedad de la figura del colaborador podía ser esgrimida como excusa para atacar otros objetivos geoestratégicos; pero también para poner en marcha un mecanismo de represión interna. De pronto, ser crítico era motivo de recelos; feministas y pacifistas eran puestos en cuarentena (FALUDI, Susan, 2009); los sospechosos de colaborar, encarcelados sin demora. No se trataba sólo de imaginar a un enemigo diabóliCo, sino de cerrar filas y cortar la posibilidad de disidencia interna. En tiempos de guerra no resulta aconsejable mostrarse comprensivo o tolerante con el adversario; pero eso es algo que ya le había sucedido antes a Tom Jeffords, protagonista de Flecha rota (Broken Arrow, Delmer Daves, 1950), arrastrado por el gentío hacia la soga por el mero hecho de sentir aprecio hacia los apaches.

El honor y valentía de Tom Jeffords está en el polo opuesto a la inmoralidad y la codicia del comanchero; en cambio, en Dos cabalgan juntos (Two Rode Together, John Ford, 1961), el mismo actor, James Stewart, interpreta a Guthrie McCabe, un comanchero de moral cuestionable que deberá purgar su alma a lo largo del camino. Ahora bien, por más que Jeffords y McCabe parezcan personajes contrarios, el amigo de los indios y el comanchero tienen un punto en común, pues ambos entorpecen el destino imperial de América: en el pasado, la conquista del Oeste y el exterminio de los pieles rojas; en el presente, el control de Oriente Medio y la erradicación de los islamistas radicales.

${ }^{13}$ La letra original es la siguiente: Tell you a story, and it's a true one / And I'll tell it like you'll understand I And I ain't gonna talk like some history man. 


\section{2. "Manifest Destiny"}

Tanto Murieron con las botas puestas (They Died with Their Boots On, Raoul Walsh, 1941) como Buffalo Bill (The Plainsman, Cecil B. DeMille, 1936) contienen una sana crítica no ya contra mercachifles y emprendedores con carromato, sino contra el capitalismo del Este como fuente del mercado de armas. El prólogo de Buffalo Bill no deja lugar a dudas: muerto Abraham Lincoln, el Oeste se convierte en zona franca para la venta de fusiles, por lo que es allí donde habrá de dirigirse el excedente de material bélico y humano de la Guerra de Secesión; municiones, rifles y soldados licenciados parten para abrir una nueva guerra con los indios y un nuevo mercado. Murieron con las botas puestas llega a culpar a los capitalistas de inocular la fiebre del oro a través de sus periódicos, con el fin de precipitar una nueva oleada de colonos y la expulsión de los indios de Colinas Negras.

"¡Lincoln dijo que hay que hacer de este país un lugar seguro!, esas fueron sus palabras" exclama Bill Hickok (Gary Cooper) en Buffalo Bill; pero la misión legada por Abraham queda empañada por los sucios intereses comerciales de los traficantes. No es infrecuente que, en el western, las iras de los indios sean espoleadas por blancos poco honrados: confederados que rechazan su derrota en Espíritu de conquista (Western Union, Fritz Lang, 1941), buscadores de oro en Pacto de honor, ladrones en Daniel Boone (David Howard, 1936), funcionarios corruptos en Gerónimo (Geronimo, Arnold Laven, 1962) o terratenientes amigos del tráfico de influencias en El caballo de hierro (The Iron Horse, John Ford, 1924). Todos estos criminales blancos parecen suponer un obstáculo para la colonización del Oeste, es decir, parecen enemigos del progreso $y$, sin embargo, son sólo una excusa argumental para encender la mecha de la auténtica fuerza opuesta al avance de los blancos: los indios americanos.

El mecanismo implica un doble movimiento de expiación: por un lado, aunque parezca culpar a unos pocos blancos deshonestos para salvaguardar la ingenuidad de los nativos, en realidad, implica que los indios son una fuerza incontrolable, peligrosa por irracional, un vigor volcánico que más convendría tener controlado; por otro lado, al individualizar la corrupción de los angloamericanos, convierte los comportamientos deshonestos en hechos excepcionales, cuando, en realidad, la especulación y el latrocinio no eran una desviación, sino el rumbo marcado para la conquista del Oeste. La propia ideología del "destino manifiesto"14 -la expansión territorial hacia el Pacíficoimplicaba un claro interés para las elites.

Las conquistas de Andrew Jackson -especulador, negrero y terrateniente algodonero- permitieron propagar el imperio del algodón; pero no fueron el único motivo detrás de la conquista del Oeste. Según Howard Zinn:

Las fuerzas que llevaron a la "mudanza"15 de los indios no nacían de los habitantes pobres de la zona fronteriza que cohabitaban con los indios. Nacían de la industrialización y del comercio, del crecimiento de las poblaciones, de los ferrocarriles y las ciudades, de la subida del precio del suelo y de la codicia de los hombres de negocios. Los indios iban a acabar muertos o exiliados, los especuladores inmobiliarios más ricos y los políticos más poderosos. Por lo que hace al pobre fronterizo, él jugaba el papel de peón, empujado hacia los primeros encuentros violentos, pero era un elemento del que se podía prescindir fácilmente.

En Ravenous (Antonia Bird, 1999) no es posible distinguir entre la forja de la nación y la ética capitalista -la supervivencia del más fuerte, el sacrificio del rival-, de manera que la crueldad, el egoísmo y la demencia dejan de ser anomalías inusitadas para convertirse en la naturaleza intrínseca de Estados Unidos. "Destino manifiesto", proclama el Coronel Ives (Robert Carlyle) mientras contempla el paisaje nevado que se extiende más allá del cementerio: "Expansión hacia el Oeste. Cuando Ilegue abril, todo empezará otra vez. Cientos de

\footnotetext{
14 La expresión "destino manifiesto" fue inventada por el columnista John O'Sullivan en 1845 a propósito de la anexión de Texas. El periodista se refería al "cumplimiento de nuestro destino manifiesto de extendernos por todo el continente otorgado por la Providencia para el libre desarrollo de nuestros millones [de habitantes] que cada año se multiplican" (O'SULLIVAN, John, 1845). Sin embargo, el destino manifiesto no era una mera cuestión de Lebensraum, sino una misión política y divina. El mismo O'Sullivan, en diciembre de ese año, ligó la necesidad de "poseer todo el continente" al "desarrollo de un gran experimento de libertad y autogobierno" (cit. DOVAL, Gregorio, 2009 p. 88). No todos secundaron la idea del destino manifiesto, pero pronto fue coreada por periodistas y políticos como Thomas $\mathrm{H}$. Benton, senador de Misuri, y acabó convirtiéndose en un eslogan que justificaba "la expansión imperialista de los Estados Unidos, propagando la convicción de que la misión que Dios eligió para el pueblo estadounidense era la de explorar y conquistar las nuevas tierras a fin de llevar a todos los rincones de Norteamérica la luz de la democracia, la libertad y la civilización. Así se impregnaba de aprobación moral el expansionismo norteamericano y sus planes anexionistas". DOVAL, Gregorio, 2009, p. 88.

15 ZINN, Howard, 2005, pp. 131-132. El término inglés empleado por Zinn es removal, que significa tanto mudanza como eliminación y que, por tanto, se refiere tanto al genocidio indio como a su deportación y confinamiento en reservas.
} 


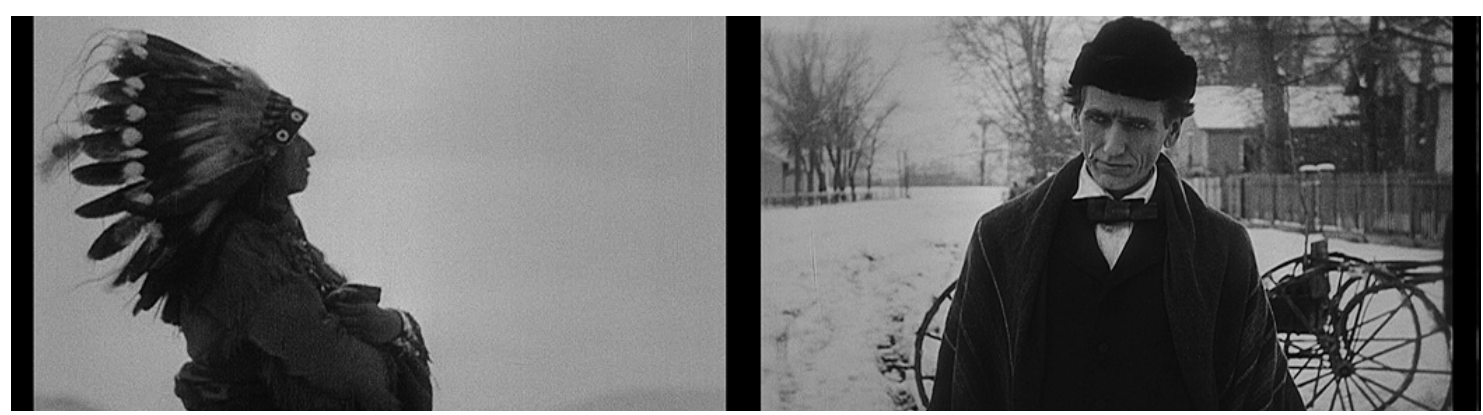

Fig. 3. El caballo de hierro (The Iron Horse, John Ford, 1924). El "Destino manifiesto" expresado a través de la mirada de Lincoln frente al contraplano del jefe indio, que mira con recelo hacia el lejano Este.

hambrientos de oro viajarán por esas montañas, buscando una nueva vida". Mientras la bandera ondea de fondo, los rostros del Coronel Ives y del capitán Boyd (Guy Pearce) miran hacia el horizonte a ambos lados de la pantalla: el primero como encarnación del deseo de acumulación y poder que conformará la patria; el segundo, como retrato de un heroísmo herido al que se obliga a elegir entre sucumbir o comulgar con un nuevo poder basado en la sangre.

Pero lejos de la pesadilla sangrienta de Ravenous, el destino manifiesto representaba en Estados Unidos un ideal elevado y civilizador. En su cuadro American Progress (1872), John Gast lo representa como una dama vestida de blanco y tocada por una estrella. En el lienzo, ella camina decidida hacia el Oeste, en una mano porta el libro de la ley $y_{1}$ con la otra, va tendiendo sobre el paisaje los cables del telégrafo; el ferrocarril y los colonos la siguen en su avance; pero los indios, bisontes y demás bestias huyen de ella e intentan cobijarse en los últimos rincones de oscuridad. El destino manifiesto de Estados Unidos es dar caza a la frontera, expandirse hasta el Pacífico e, imponer, en todo el imperio, la civilización de los hombres blancos.

También el relato de El caballo de hierro avanza hacia el Oeste, a la par que los raíles y las traviesas que van siendo clavadas en la tierra, siguiendo el plan trazado por Abraham Lincoln. Durante la primera secuencia de El caballo de hierro, la mirada de Lincoln a menudo queda fija en un lugar fuera de campo, perdido en la lejanía: "Siente el impulso de una gran nación empujando hacia el Oeste... Contempla lo inevitable", aclara el intertítulo.

El rodaje de El caballo de hierro resultó casi tan épico como la historia que nos cuenta: ${ }^{16}$ la construcción del ferrocarril transcontinental. Producida por la Fox como respuesta al éxito de la epope- ya de la Paramount, La caravana de Oregón (Covered Wagon, James Cruze, 1923), la película de Ford supone un capítulo fundamental en ese gran cantar de gesta cinematográfico que narra, a la manera de los mitos, el avance de la nación hacia el Oeste; sin embargo, el cine de John Ford rara vez oculta los problemas y contradicciones que carcomen el orden dominante. El caballo de hierro elucida una y otra vez que la vía férrea es una metáfora de la nación unida de costa a costa, una sutura de la herida entre confederados y yanquis, que trabajan también mano a mano con los chinos, italianos e irlandeses: el legado de Lincoln es una nación reunida, en la que el montaje que enfrentaba planos de trabajadores del Este y el Oeste confluye en un solo plano general en el que la muchedumbre celebra la conclusión de la línea férrea.

Sin embargo, el destino manifiesto consignado en la mirada fuera de campo del joven Lincoln tenía ya, desde el comienzo del filme, un contraplano opuesto. Poco después del plano de Lincoln escrutando el Oeste, una segunda secuencia nos presentaba al jefe Big Tree de perfil, mirando hacia el Este, augurando un choque inevitable (Fig. 3). La inevitabilidad del progreso legitima, a posteriori, el atropello de los pueblos indios que han de acomodarse porque no hay alternativa; pero acomodarse significa aquí ser expulsado, confinado o exterminado. Incluso en películas supuestamente progresistas, como Flecha rota, llega un punto en el que hasta el jefe apache debe adoptar una postura realista ante lo imparable del progreso. En Flecha rota, comenta Peter Biskind (1983, p. 236), "Cochise habla como un realista. La 'realidad', en este caso, es la realidad del poder estadounidense, pero en los westerns es vista en términos generales como la Historia, el Progreso, el Paso del Tiempo, el Destino Manifiesto, etc". La "inevitabilidad de la Historia" se convierte, por tanto, en el

${ }^{16}$ GALLAGHER , Tag, 2009, p. 50. 
argumento fatal e irrefutable al que deben plegarse los indios.

En el western, cualquier indio que se yerga contra esto es un loco, un ingenuo, un insensato. De idéntica manera, durante la invasión de Afganistán, los talibanes eran presentados como una anacronía casi medieval, como una locura opuesta a la historia y al paso del tiempo. Pero esto era algo que ya apreciábamos en El caballo de hierro, con los indios que galopan en dirección opuesta al tren. El indígena y el ferrocarril son dos fuerzas enfrentadas, pero dos fuerzas desiguales, tal como se demuestra cuando intentan detener la locomotora tensando una cuerda sobre las vías; el tren, obviamente, los derriba de sus monturas. Ciertamente, hubo ataques de los sioux y los cheyenes durante la construcción del ferrocarril, pero rara vez de la envergadura de las cargas a caballo filmadas por Ford.

Las guerras indias fueron muchas, las condiciones de batalla variaban continuamente, las tácticas eran distintas. Por lo general, los apaches realizaban incursiones en busca de alimento (BARRET, Stephen M., 1975, pp. 101-102) o guerras en venganza por la muerte de un familiar (WORCESTER, Donald E., 2013, pp. 25-26); los comanches eran un imperio económico y una potencia militar capaz de poner en jaque a los colonos angloamericanos (HÄMÄLÄINEN, Pekka, 2011, p. 12); en 1835, los seminolas rechazaron su expulsión y combatieron organizados en guerrillas durante los ocho años siguientes (ZINN, Howard, 2005, pp. 138-139); pese a ello, como veremos en el próximo epígrafe, el western representará a los indios y a sus guerras siguiendo unas convenciones concretas y condicionadas por el contexto histórico en el que se realizaban las películas.

\section{Indios en pie de guerra}

La Guerra contra el Terror se sustentaba en la idea del choque entre las fuerzas de la Historia y el progreso y un enemigo concebido como la alteridad más radical. Se trataba de una reedición del "destino manifiesto" contra los pieles rojas y contra cualquiera que trate con ellos. El paralelismo es claro; pero laxo, pues resultaría aplicable a infi- nidad de conflictos. Debemos, por tanto, preguntarnos si existen motivos específicos en el relato cultural de las Guerras indias que se reutilicen en el imaginario de la Guerra contra el Terror. Para ello, debemos centrarnos en el aspecto nodal de las guerras posteriores al once de septiembre -el terrorismo- y explorar en qué medida podía ser aprehendido y explicado desde la mitología estadounidense.

El término "terrorismo" es convenientemente laxo, lábil y maleable, útil para el poder que lo define y que posee, en consecuencia, la potestad de determinar quién es un terrorista. Sin embargo, la lógica del terrorismo es la propia de una guerra asimétrica. En ella se solapan las tácticas de la guerrilla -"rehuir la lucha abierta, hacerse invisible y atacar a traición"- con "el objetivo exclusivamente propagandístico de dirigir la atención pública sobre la propia causa". ${ }^{17}$ En este sentido, y desde el punto de vista de los colonizadores, numerosos actos de guerra indígenas podrían verse, retroactivamente, como terroristas. Los apaches, por ejemplo, atacaron sin piedad los ranchos y ciudades de Sonora, Nueva Vizcaya -hoy Chihuahua-, Nuevo México y Arizona; en 1840, la acción combinada de comanches, por un lado, y apaches, por otro, dejaron el norte de México como "tierra despoblada" (WORCESTER, Donald E., 2013, p. 73); ahora bien, no se trataba de una mera guerra de saqueo y expulsión de los colonos, tampoco era sólo una venganza por los hermanos esclavizados en haciendas, deportados a La Habana o asesinados para cobrar por sus cabelleras; se trataba también de aterrar a los colonos hasta el punto de poder tomar sus caballos y mulas a plena luz del día, ante las mismas narices de los reclutas de los presidios. ${ }^{18}$

Desde nuestra sensibilidad política actual, podríamos entender este hostigamiento como un intento de dominar por el terror o, por lo menos, como una manera de influir en el rumbo de la historia a través de una serie de actos de terror. Sin embargo, identificar a los indios con terroristas plantea un problema de índole ética, pues supondría aplicar un término peyorativo y difamatorio a pueblos que fueron víctimas de la invasión, la deportación y el genocidio. ${ }^{19}$ Pese a ello, es preciso in-

\footnotetext{
17 Véase GIL CALVO, Enrique, 2003, pp. 249-252. En referencia a las tácticas de guerrilla, el autor comenta una estrategia que encaja bien con las Guerras indias: "La táctica de la sorpresa permite atacar al enemigo en sus puntos débiles cuando se cree más seguro, está desprevenido y permanece indefenso [...]. La táctica de la invisibilidad exige disponer de un territorio y una población en los que camuflarse miméticamente hasta desaparecer fuera de la vista del adversario".

${ }_{18}$ Un presidio era una fortificación fronteriza, dotada de una guarnición de soldados y encargada de la vigilancia y administración territorial.

19 De hecho, desde Hernán Cortes o las guerras contra los pequotes (ZINN, Howard, 2005, p. 26), los europeos utilizaron el ataque sistemático a los civiles como manera de aterrorizar al enemigo.
} 
dagar en la representación cinematográfica de las guerras indias para comprender la función de este relato como patrón ideológico y cultural de la Guerra contra el Terror. También los vaqueros pueden parecernos personajes de otra era $y_{\text {, sin }}$ embargo, siguen funcionando como emblemas del individualismo estadounidense, figuras que condensan en una imagen los valores predilectos del neoliberalismo (HOBSBAWM, Eric, 2014, pp. 257-272). ${ }^{20}$

Asimismo, los mitos de mujeres raptadas por los indios pueden parecernos igualmente lejanas $y$, sin embargo, resurgieron tras el 11 de septiembre como legitimación del nuevo orden. El mito de la cautiva blanca apareció para dar sentido a la conquista del territorio y el exterminio del enemigo: una mujer blanca es raptada y mancillada por los indios, por lo que debe ser vengada y, de ser posible, rescatada. ${ }^{21}$ La única manera de salvaguardar hogar y mujer de la amenaza de los indios, será erradicarlos por completo. No es casual, por tanto, que en el western el ataque de los indios se represente una y otra vez como un ataque contra las granjas y las familias de los colonos ni, tampoco, que el mito de la cautiva resurja con fuerza tras el derrumbe del World Trade Center, un atentado cuyo relato mediático enfatiza que se trata de un ataque contra el hogar de los estadounidenses. Los discursos coinciden y, así como los arquetipos del cowboy y la cautiva blanca siguen funcionando como ideales de héroe y víctima, también los rasgos que se atribuyeron los indios siguen proyectándose sobre los nuevos enemigos de Estados Unidos.

El soldado que agoniza cabeza abajo en la secuencia pregenérica de Mayor Dundee (Major Dundee, Sam Peckinpah, 1965) es una advertencia: "Soldado, soy Sierra Charriba. ¿Quién volverá a atreverse?", le dice el caudillo apache (Michael Pate) antes de prender una hoguera bajo su testa. Los indios ocultarán su rastro en el polvo del desierto y la hojarasca de la selva, pisarán sólo la roca, atarán por la cola a los caballos con reatas para embrollar su propio rastro $y$, sin embargo, no desearán borrar ninguna de sus huellas cuan- do arrasen las granjas y chozas de los colonos. Cuando Jake Cutter y Paul Regret avistan humo sobre el rancho en Los comancheros, la cámara efectúa un pequeño travelling para revelarnos la escala de la devastación: fuegos, flechas, cadáveres despatarrados, trastos esparcidos, un perro ensartado y dos muertos colgando por los pies en la puerta del cercado. Los comanches han puesto en escena un festín de muerte, todo ha sido dispuesto para ser visto, ${ }^{22}$ para golpear a la mirada, y así lo subrayan los primeros planos de Paul y Jake contemplando los granjeros que cuelgan cabeza abajo.

El espectáculo de los despojos proclama una admonición bien alta y clara: marchaos, no os queremos aquí. Podríamos intuir una continuidad entre esta escenificación de la violencia y la búsqueda de atención mediática de los grupos terroristas actuales, pues en ambos casos se trata de hacerse visible, de irrumpir en el discurso a través de un acto brutal e inaudito. Sin embargo, los ataques de los indios no eran necesariamente espectaculares. Gerónimo, por ejemplo, resulta lacónico al relatar sus escaramuzas: "Nos pusimos al acecho en un lugar en que la carretera cruzaba unas montañas, y cuando pasaban carreteros mexicanos los matábamos, cogíamos lo que necesitábamos y destruíamos el resto" (BARRET, Stephen M., 1975, p. 102) (Fig. 4). Quienes ponen en escena los faustos de la carnicería india son, en cambio, los blancos que cuentan las historias y dirigen las películas, pues no hay mejor justificación para el ataque que la venganza por un crimen pretérito, mítico, mejor cuanto más atroz, mejor cuanto más vistoso. La granja reducida a cenizas, el plantío sembrado de cadáveres: no sólo se trata de crear un pathos dentro del relato, sino de situar a los indios como responsables primeros, de remontar su crimen en el tiempo hasta la era de los mitos. Olvidemos las reservas, olvidemos la conquista; por virtud del espectáculo, el suyo se convierte en un pecado original a posteriori.

De igual manera, los atentados del once de septiembre no consisten sólo en aviones y torres, si-

\footnotetext{
20 Véase también CLEMENTE FERNÁNDEZ, María Dolores, 2009, p. 126, donde la autora identifica los rasgos del héroe del western, entre los que destaca la defensa de los desvalidos como imperativo moral, la valentía, la lealtad y el individualismo. Este último rasgo nos interesa por la relación que se establece entre el héroe individuo -el vaquero- y el enemigo como masa -los indios-: "[U]no de los recursos más utilizados para acentuar la mayor calidad física, moral y espiritualidad del héroe con respecto a sus enemigos es representar a éstos en bloque, sin personalizar ni individualizar".

${ }^{21}$ FALUDI, Susan, 2011; PÉREZ OCHANDO, Luis, 2015, pp. 407-422; ORTELLS, Elena, 2012, pp. 98-101.

22 El decoro clásico solamente nos ahorra la visión de la niña muerta, suplantada por una metonimia, la muñeca de porcelana y trapo que Jake recoge entre sus manos.
} 


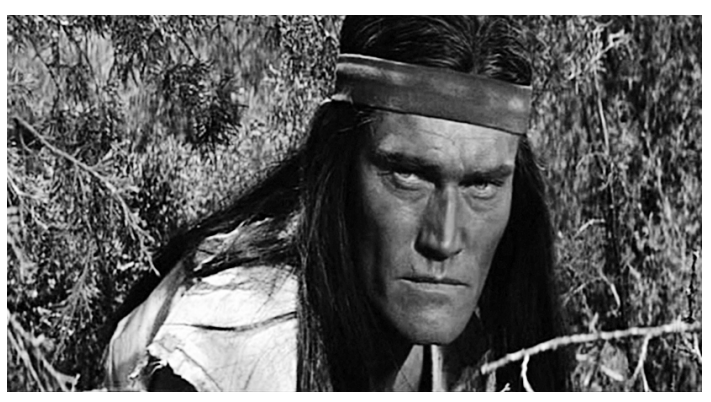

Fig. 4. Gerónimo (Geronimo, Arnold Laven, 1962). Gerónimo prepara una emboscada.

no en millones de televisores. Desde ellos se teje una respuesta, un discurso y un "nosotros" que no dejan espacio a las palabras y motivos del otro. La Guerra del Terror se articula como una guerra contra el mal, como una cruzada bíblica. ${ }^{23}$ Blackwater -el mayor ejército de mercenarios contratados en Irak- tenía por propietario al criminal y traficante de armas Erik Prince, que declaraba sentirse "como un cruzado cristiano encargado de eliminar a los musulmanes y a la fe islámica de la faz de la tierra". ${ }^{24}$ Como ya sucedía en el western, la civilización quedaba de nuestra orilla; la otredad, por el contrario, se abandonaba al reino de lo irracional, lo incomprensible y lo salvaje.

En La venganza de Ulzana (Ulzana's Raid, Robert Aldrich, 1972), un grupo de chiricauas escapa de la reserva y se dedica a asesinar, torturar y violar a todos los colonos que encuentra por el camino; sus tácticas son el sigilo y la emboscada, no tienen piedad, pero tampoco motivos políticos, ni siquiera racionales: la crueldad les otorga poder espiritual, eso es todo. La irracionalidad, como veremos, será uno de los nexos cruciales entre las representaciones del indio y del terrorista; pero antes deberemos abordar las convenciones de representación que el western deparaba a los indios en pie de guerra.

Poco antes de que Fort Apache (John Ford, 1948) entre en su tramo final, el capitán York (John Wayne) y el sargento Beaufort (Pedro Armendáriz) cabalgan entre arena y rocallas bajo un sol de justicia, portan bandera blanca y van en busca de los apaches. Un destello en los peñascos marca el lugar y los militares se encaminan trotando hacia el desfiladero. Desde lo alto del barranco, la cámara espía a los jinetes y va siguiendo su avance a través de la garganta. Un plano inserto nos muestra a dos apaches que vigilan también a los jinetes. Tras la irrupción de los dos primeros indios, el plano sigue deslizándose sobre el barranco para revelar a una hilera de apaches que aguarda inmóvil, entre las rocas. Mezcaleros y chiricauas, Cochise, Alkesay, Satanta y Gerónimo: la nación apache al completo reunida en las montañas. La secuencia apuntada aporta tres elementos fundamentales en la representación clásica de los guerreros de piel roja: profusión, sigilo y unión a la tierra.

Para el western clásico, los indios en pie de guerra son siempre numerosos, no comando sino legión, y, cuando cargan, atruenan la tierra como un redoble de tambor. Corceles pintos, pinturas de guerra, coronas de plumas, la legión india al galope es un espectáculo plástico y cinético al que la cámara no puede resistirse: en Winchester 73 (Anthony Mann, 1950) los indios se abaten ola tras ola sobre un grupo de soldados y colonos apiñados en torno a una carreta; en Buffalo Bill los cascos de los caballos cheyenes baten el agua del río y son tantos que no sabemos dónde acaba la carga; en la batalla final de Murieron con las botas puestas, el montaje redobla el galope de los caballos indios, el plano se amplía, la cámara se aleja en grúa y, aun así, no abarca el ejército de sioux, cheyenes y arapahoes, por todas partes llegan, por todos lados los rodean (Fig. 5). Incluso cuando el cine se acerca a pueblos que actuaban en pequeñas bandas -como los mezcaleros y chiricauas de Fort Apache-, prefiere mostrar siempre un enemigo temible, bien armado, numeroso como la arena. ${ }^{25}$

Hay mucho de autojustificación aquí, también algo de mala conciencia. El western cinematográfico se funda y asienta mucho después del exterminio indio $y$, por ello, presenta a los indios como un ejército poderoso, tan potente como el yanqui, una hueste contra la que había que resistir con to-

\footnotetext{
${ }^{23}$ En Estados Unidos, "el terrorismo es visto como algo extraordinariamente maligno, como la obra de unas fuerzas tenebrosas que deben ser derrotadas y eliminadas. [...] En sí mismo, esto no tiene nada de nuevo. La división del mundo en buenos y malos es un elemento reiterativo del pensamiento estadounidense" (GRAY, John, 2004, p. 134).

24 FONTANA, Josep, 2011, p. 162.

25 De manera excepcional, Apache (Robert Aldrich, 1954) nos muestra sabotajes y escaramuzas a pequeña escala, telégrafos cortados y carros de pólvora que estallan, pero ésta es la obra de un hombre solo, Massai (Burt Lancaster), la resistencia de quien se considera el último hombre libre de su raza.
} 


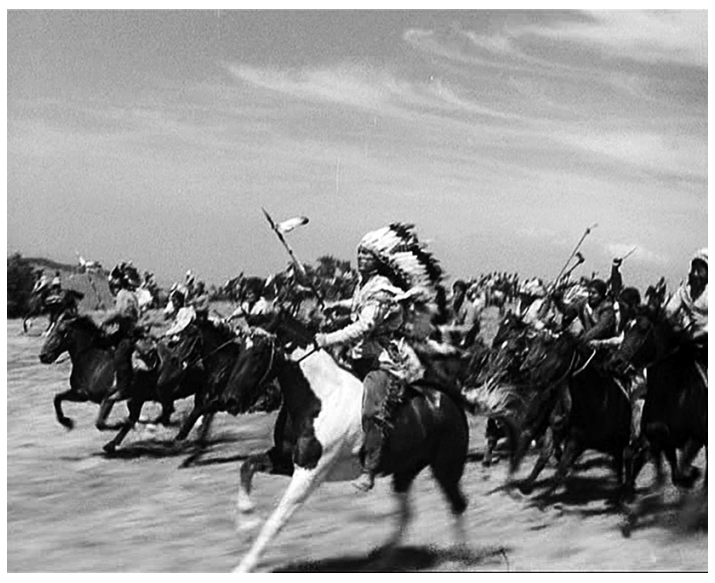

Fig. 5. La carga final de Murieron con las botas puestas (They Died with Their Boots On, Raoul Walsh, 1941).

das las armas. ${ }^{26}$ Esto pudo llegar a ser cierto en casos como el de los comanches, pero en el cine responde más bien a una construcción ideológica, determinada por el contexto histórico de los filmes. La gran era dorada del género se produce, de hecho, durante la Segunda Guerra Mundial y las dos décadas siguientes, con un imaginario bélico dominado todavía por grandes batallas y enormes ejércitos.

Un año antes de que Estados Unidos entrase en la contienda internacional, Paso al Noroeste (Northwest Passage, King Vidor, 1940) mostraba ya patrones ideológicos e iconográficos bien definidos: un enemigo inhumano, un choque entre dos grandes facciones, un compromiso con una misión elevada y heroica, etc. Durante la secuencia del ataque de los rangers al fortín de los abenaki, contemplamos una acción militar de una brutalidad pasmosa: incendian las cabañas, disparan a diestro y siniestro, matan a un tropel de indígenas y los rematan a bayonetazos. Consumada la masacre, los rangers viajan al fuerte a través de un purgatorio de hambre atroz, heridas de guerra, desesperación y locura; pero éste no es calvario ni castigo por los pecados cometidos, sino el arduo camino de la perfección del guerrero. El filme concluye con un tono triunfal, las penurias de los patriotas son recompensadas y nuestro pusilánime universitario (Robert Young) se ha convertido en todo un hombre. La conclusión moralizante del filme es perturbadoramente clara, ${ }^{27}$ tan nítidamente definida como lo estaban los bandos de rangers y abenakis.

Por el contrario, La venganza de Ulzana se estrena en un momento de la Guerra de Vietnam en el que las atrocidades bélicas -la ofensiva del Tet, la masacre de M Lai...- han ido minando la opinión pública. ${ }^{28}$ La violencia se desborda, el juicio moral se emborrona, la brutalidad de los indios es tan grande como el odio de los blancos. Ulzana (Joaquín Martínez) y sus hombres ya no cargan en tropa sino que se emboscan en guerrilla. Como el Vietcong, su mejor arma es el silencio.

El sigilo es el segundo de los rasgos de la representación clásica del indio, que advertíamos ya en la citada secuencia de Fort Apache. En el cine de Hollywood, los indios son la flecha salida de ninguna parte en Río de sangre (The Big Sky, Howard Hawks, 1952); un chotacabras que emprende súbitamente el vuelo en el ocaso y anuncia que algo acecha la granja de Centauros del desierto (The Searchers, John Ford, 1956); los ojos de los hurones pintados que, invisibles tras la espesura, aguardan la señal de ataque en El último mohicano (The Last of the Mohicans, Michael Mann, 1992). Pero era preciso conjugar silencio y raudal, espera y explosión: una táctica narrativa común era mostrar a los indios emergiendo de pronto en tromba tras una loma o un ligero desnivel, para desbordarse acto seguido en una riada de alazanes, atronando el horizonte, llenando todo el encuadre. Hasta ese momento del estallido, los indios aguardarán silentes en un inquietante fuera de campo que los vaqueros inspeccionan con el rifle amartillado entre las manos.

En Estación comanche (Comanche Station, Budd Boetticher, 1960), Jefferson Cody (Randolph Scott) y un par de buscavidas escoltan a la cautiva liberada (Nancy Gates) a través de las roquedas de Long

\footnotetext{
${ }^{26}$ La pregunta incómoda, la angustia soterrada, de este planteamiento consiste en contrastar aquellos planos y secuencias de ejércitos tan vastos que desaparecían en la distancia con el menguado número de indígenas que sobreviven hoy en Norteamérica. ¿Adónde fueron? ¿Qué fue de ellos? Cuando vemos a los indios cayendo, como moscas, hilera tras hilera, ante los rifles blancos, estamos asistiendo a una representación del genocidio que, sin embargo, no es capaz de reconocerse a sí misma como tal.

${ }^{27}$ King Vidor planteaba una secuela en la que los contornos morales de los personajes quedarían más desdibujados, pero el poco éxito económico del filme impidió que el proyecto siguiera adelante.

28 CASAS, Quim, 1994, pp. 212-213, por ejemplo, la describe como un "espejo deformante en clave westerniana de los conflictos bélicos en los que Estados Unidos se entrometía sin que se lo pidieran".
} 
Pine. De pronto, los jinetes se detienen allí donde la senda del derrocadero se dilata en un llano a cielo abierto. Cody decide atravesar la planicie. Parece vacía, pero la música dramática y las miradas nerviosas a un lado y a otro del fuera de campo nos anuncian que los indios aguardan tras cada roca. En Territorio apache (Apache Territory, Ray Nazarro, 1958), un indio surge detrás de una yuca, cuchillo en mano, como aparecido de pronto, como materializado del polvo y del aire mismo. Logan (Rory Calhoun) vence a este apache pero, poco después, queda acorralado por los gileños en Papago Wells junto a unos cuantos soldados y civiles, pocos y mal avenidos. Parapetados tras las rocas, los personajes sitiados disparan hacia el desierto. Las flechas de los gileños Ilegan silbando, la pólvora quemada humea entre las dunas, pero en el ataque los indios son invisibles hasta que, de pronto, irrumpen armados por cualquier lugar del encuadre.

Pero esta cualidad de la invisibilidad y el sigilo no es sino un trasunto del principal rasgo atribuido al indio: su pertenencia al paisaje. En el óleo Indians Viewing Landscape (1827), Thomas Cole no sólo mostraba a dos nativos, de espaldas a nosotros, con la mirada perdida en la distancia salvaje; lo que Thomas Cole pintaba eran los montes, bosques y barrancos como espejo de ese rostro de los indios que nosotros no podemos ver. Los indios no miran al paisaje, son el paisaje, la pureza virgen de la tierra indómita. De la misma manera, John Ford nos presentaba a sus indios de Fort Apache como figuras hieráticas, dignas, silentes, como las rocas del barranco en que se encuentran, como la tierra yerma de la que brotan y a la que regresan. Según escribe Gallagher (2009, p. 343-344) a propósito de Fort Apache:

Por eso el polvo (la tierra) es su aliado constante: el polvo lanzado por Cochise en señal de que va a enfrentarse a la caballería [...]; las nubes de polvo que advierten a York sobre la cercanía de los apaches; las nubes de polvo que los indios producen para despistar a Thursday; el polvo que engulle al regimiento atrapado; el polvo en el que los apaches desaparecen tras plantar el pendón del regimiento frente a York y que barre la tierra que pisan los hombres de York.

Sin embargo, esta identificación ideológica del indio con las fuerzas de la naturaleza implica también considerarlo como lo irracional, no sólo como lo incivilizado, sino como aquello inaccesible al impulso civilizador. Tal es la paradoja que minaba, en el pasado, la idea de destino manifiesto y que carcome, en el presente, el proyecto neoconservador de democracia global, pues no es posible evangelizar al otro sin reconocerlo como semejante y como ser humano.

\section{El destino manifiesto y las fuerzas de lo salvaje}

Cuando el indio se convierte en el héroe del western, a menudo es interpretado por una estrella blanca: Robert Taylor en La puerta del diablo (Devil's Doorway, Anthony Mann, 1950), Rock Hudson en Raza de violencia (Taza, Son of Cochise, Douglas Sirk, 1954), Burt Lancaster en Apache, Chuck Connors en Gerónimo, Audrey Hepburn en Los que no perdonan (The Unforgiven, John Huston, 1960)... El cine clásico podía pasar por alto el atentado contra la verosimilitud de que Cochise, Gerónimo o Massai hablaran inglés, tuvieran los ojos azules o embadurnaran su piel pálida con un pringue cobrizo; sin embargo, ninguno de estos filmes hubiera podido funcionar sin el magnetismo y la identificación espectatorial que sólo las estrellas de Hollywood podían garantizar. La única manera de entender al indio es fingir que podemos llegar a parecernos a él, no acercándonos a él sino aproximándolo a nosotros. Desde Flecha rota hasta Pocahontas (Mike Gabriel y Eric Goldberg, 1995), el amor romántico -ese narcótico universal descubierto por Hollywood- hace entrada para permitirnos identificarnos con los indios. En Flecha rota, Tom Jeffords aprende la lengua y las costumbres de los apaches, pero son nuestros valores los que se proyectan sobre los indios que él encuentra en el poblado.

La puerta del diablo, Flecha rota, Apache, Raza de violencia u otros westerns pro-indios posteriores a la Segunda Guerra Mundial bien podrían responder al remordimiento propio y la vergüenza ajena de los campos de exterminio; sin embargo, la construcción cultural del indio norteamericano se había caracterizado históricamente por mostrarlo como una otredad irreductible y opuesta al impulso civilizador. Tal como señala Grégoire Chamayou (2012, pp. 42-55), las paradojas ideológicas atragantaron la justificación de la colonización de Sudamérica: el mismo pensamiento humanista que hacía posible la defensa de los indios -recordemos a Bartolomé de las Casas- también permitía legitimar su exterminio: los indios sólo podrían ser convertidos si poseían un alma; pero, de ser así, no sería lícito esclavizarlos o exterminarlos. La idea aristotélica de la dominación chocaba con el principio cristiano de la conversión: la primera presuponía la desigualdad entre los hombres; la segunda, el dogma de la unidad del género humano. En consecuencia, la dominación pasó a basarse en 
una semejanza a Dios mayor a la de los salvajes, en una humanidad superior y opuesta a la de aquellas otras naciones que vivían contra natura y, por tanto, alejadas de Él. El humanismo revelaba así su reverso oscuro, pues "la invocación política de lo humano implicaría necesariamente la denominación de lo inhumano como su doble hostil. Luchar en nombre de la humanidad supondría necesariamente deshumanizar a los enemigos en una lógica que lleva al exterminio" (CHAMAYOU, Grégoire, 2012, p. 49).

En cambio, los angloamericanos muy pronto concibieron al indio como parte de la tierra salvaje y del bosque, del desierto y el huracán, de la sangre y lo irracional. ${ }^{29}$ Para la civilización racionalista, la Naturaleza era un objeto de conquista; en consecuencia, los indios -considerados parte de la misma- se convertían también en una frontera que destruir o sojuzgar. Tal como recoge Richard Slotkin (1973, pp. 17-21), para los blancos los indios estaban ligados a Moira, el principio femenino de divinidad, más viejo que los dioses, la matriz prehistórica de los impulsos, el sueño y el inconsciente, el crisol del caos y la violencia, del hambre y del placer, de la disolución del yo enajenado de amor. Frente a Moira está Themis, la figura patriarcal que rige la actividad y la consciencia, el principio civilizador de la filosofía y la agricultura. $^{30}$

Hasta cierto punto, tanto la espiritualidad como la estructura social india tenían una vinculación a la tierra mayor a la europea. Después de ser capturado, el jefe Inmatuyalatket pronunció un discurso en defensa de su pueblo, los nez percés, el 14 de enero de 1874: "Nosotros éramos como el ciervo [...]; estábamos contentos dejando que las cosas permanecieran como el Gran Espíritu las creó. Ellos no, y cambiaban los ríos y las montañas cuando no les gustaban" (JEFE JOSEPH, 1998, p. 34). Por el contrario, la tala de un gran árbol es el acto fundacional que señala la llegada a la tierra prometida de los colonos en Horizontes lejanos (Bend of the River, Anthony Mann, 1952) o en Camino de Oregón (The Way West, Andrew McLaglen, 1967). El choque entre nativos y colonos no era sólo de índole económica o estratégica, en él se enfrentaban también dos maneras opuestas de racionalidad y comprensión de la naturaleza: la de los blancos y la de los nativos. Sin embargo, a la comprensión india de la naturaleza le fue negada, desde el principio, la categoría de lo racional.

Los pioneros puritanos imaginaban a los indios como carentes de cultura o civilización, eran la otredad; en consecuencia, proyectaban sobre ellos sus propios miedos reprimidos $y$, una vez fuera del orden racional, eran descritos como monstruosos. Así, argumenta Robin Wood (1986, p. 72), "la conexión entre esta visión del indio y la represión del puritano se hace obvia: es un ejemplo clásico y extremo de la proyección en el Otro de aquello que ha sido reprimido de la propia identidad, con el fin de poder desacreditarlo, repudiarlo y, si es posible, aniquilarlo". ${ }^{31}$

En La venganza de Ulzana, nuestro punto de vista no es el del curtido McIntosh (Burt Lancaster) -ya de vuelta de todo y que considera a los indios como parte de un paisaje inhóspito-, sino el del lugarteniente Garnett (Bruce Davinson), el hijo de un párroco, un alma cándida cuya visión cristiana del mundo choca continuamente con la crueldad de unos y otros, con una racionalidad -la de los indios- que le resulta ininteligible. Mclntosh y Garnett encuentran el cadáver de un colono amarrado a un árbol, con el rostro, el vientre y los pies abrasados a fuego lento y la cola de su perro embutida en la boca: "Los apaches tienen sentido del humor, no es un humor comprensible. Algunas cosas les parecen divertidas", comenta McIntosh. Como a Garnett, a los colonos la racionalidad de los indios les resultaba ajena, opuesta a la moral y contraria al imperativo civilizador del destino manifiesto. No bastaba con dejarlos fuera del orden, había que considerarlos monstruosos.

En El jardín del diablo (Garden of Evil, Edward Dmytryk, 1954), los exploradores avanzan por el despeñadero y traspasan, a salto de caballo, la frontera que marca la entrada a la tierra de los monstruos, un territorio agreste de iglesias en ruinas y misiones destruidas por los indios y por las fuerzas de la naturaleza. En Bone Tomahawk (S. Craig Zahler, 2015), el pasaje es árido, duro, inmisericorde, y los nativos forman parte de él, se embadurnan con la tierra y moran bajo ella; Zahler

\footnotetext{
29 Tan asumida está la unión de los nativos a las fuerzas telúricas que un filme como Desapariciones (The Missing, Ron Howard, 2003) integra un par de secuencias que escenifican los poderes sobrenaturales del brujo apache (Eric Schweig) sin que ello implique la ruptura de su registro realista.

30 A propósito de Moira y Themis, véase HENDERSON, Joseph L., 1967, pp. 2-6.

31 En la misma línea, ASTRE, Georges; HOARAU Albert-Patrick, 1975, p. 252, argumentan que, para los colonizadores, el indio se convirtió "en la víctima propiciatoria encargada de absorber los inconfesables impulsos de los blancos".
} 
les niega el don del habla e incluso la apariencia humana: ellos silban como aves nocturnas, su piel está perforada con cuernos, astillas y huesos de animales, acechan en las quebradas y comen carne humana (Fig. 6). "Estamos en el infierno", dice uno de los personajes.

Pero las amistades entre los indios y el diablo vienen ya de lejos. En El último mohicano, James Fenimore Cooper atribuía continuamente rasgos demoníacos a los hurones: sus actos eran una "fiesta satánica", en sus obras se palpaba "la huella de la mano del diablo" (COOPER, James F., 1997, pp. 287-296). Tras estampar la cabeza de un bebé contra una piedra y hundir su tomahawk en los sesos de su madre, un hurón da comienzo a la masacre que marca el ecuador de El último mohicano:

La actitud de resistencia solamente servía para enfurecer aún más a los asesinos, quienes continuaban golpeando a sus víctimas cuando ya hacía tiempo que estaban sin vida. El derramamiento de sangre fue tal que llegó a semejarse a la formación de un torrente sobre la tierra y, a medida que los salvajes se acaloraban y enloquecían más por la escena, algunos incluso se arrodillaban para beber abundantemente del enrojecido manantial, como criaturas salidas del infierno (COOPER, James F., 1997, p. 286).

Lo diabólico, lo irracional, las pasiones desatadas, las cavernas, las ruinas, el sobresalto, los paisajes sublimes, el malvado Magua e incluso el dúo femenino -la una rubia, la otra morena-: todo en El último mohicano reproduce las convenciones de la literatura gótica (CROW, Charles L., 2009, pp. 32-33); sin embargo, el paisaje adquiere aquí una resonancia autóctona, pues ya no nos extraviamos en los pasadizos subterráneos de castillos, criptas y monasterios, sino en la amplitud sublime de los bosques, los barrancos, las llanuras y los torrentes, al que pertenecen y del que forman parte los nativos americanos, que pasan a ser considerados una fuerza no sólo hostil, sino abiertamente diabólica.

De la misma manera que los caballos habían de ser domados y la tierra, roturada, los indios debían ser aniquilados; pues, siendo el indio un ser irracional y desalmado, su evangelización y redención quedaban más allá del alcance humano: "Algunos creéis que el indio es como un animal salvaje. Esto es un gran error. Os explicaré todo sobre nuestro pueblo y luego podréis juzgar si el indio es o no un ser humano", afirmó en su defensa el jefe Joseph (1998, p. 13).

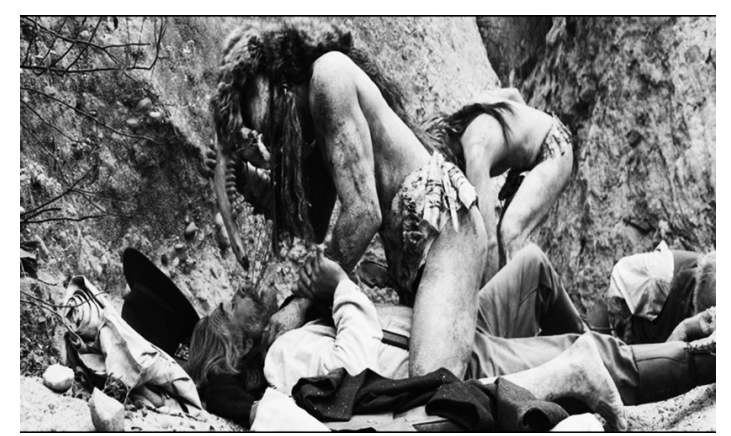

Fig. 6. Bone Tomahawk (S. Craig Zahler, 2015). Los indios como fuerzas de lo irracional y lo salvaje.

Sin embargo, cuando el enemigo había dejado de ser humano, la violencia adquiría carta blanca; cuando se luchaba contra el mal, ya no hacían falta los porqués: "Atrapé a un indio. No era tan bravo como él pensaba y acabó hablando".32 Las razones para deshumanizar -y demonizar- a indios de entonces y talibanes de hoy resultan palmarias. Con ello, evitamos dar cuenta de nuestros actos, nos absolvemos a nosotros mismos de nuestros pecados. Uno de los aspectos más significativos -y lamentables- de la Guerra contra el Terror es que la tortura se normaliza, se legitima, se abre al debate y, por lo tanto, pasa a concebirse como una opción concebible, tolerable, incluso aceptable. Como ironizaba John Gray:

La creencia de que la tortura está siempre mal pasa de pronto a ser un prejuicio heredado de una filosofía obsoleta. Necesitamos liberarnos de esa creencia que dictamina que cuando se tortura a un terrorista se violan los derechos humanos. [...] en una sociedad realmente liberal, los terroristas gozan del derecho inalienable a ser torturados. (GRAY, John, 2006, p. 144).

Abu Ghraib, Guantánamo, Bagram o la invasión de Irak: las acciones "extralegales" contra personas y contra estados soberanos son la norma en la Guerra contra el Terror. Se abre un periodo de justicia más allá de la ley o del Estado de Derecho. En el western no hacían falta tribunales para matar a un indio, tampoco jueces ni sentencias: se le mataba y punto. A fuerza de repetida, hemos interiorizado la imagen sin llegar a preguntarnos por la naturaleza sumaria de estas ejecuciones. La alteridad salvaje y demoníaca del piel roja ha quedado tan firmemente asentada que sobra cualquier otro razonamiento.

Parece la misma guerra, el mismo polvo, la misma emboscada, el mismo desierto $y$, sin embargo, ca-

32 L'AMOUR, Louis, 2014, p. 80. 
be un distingo crucial entre el western y los discursos de la Guerra contra el Terror: en el western, el indio es demoníaco porque ejerce la tortura; en la Guerra contra el Terror, ${ }^{33}$ el yihadista es demoníaco y, por tanto, sufre la tortura. Si el western ayudó a asumir la ejecución de los nativos como un acto de defensa - ¿acaso no arrancan ellos el pelo y la piel de las cabezas?- 24 (Robert Cochran, Joel Surnow, 2001-2010) y otras ficciones posteriores al 11-S justificaban la tortura como única manera de plantar cara al terrorismo y salvar a mujeres y niños inocentes. ${ }^{34}$ Occidente sigue abanderando la civilización como argumento; pero su lucha lo acerca cada día más a la barbarie. En algún lugar del desierto, entre el polvo de la guerra, nuestros pasos se extravían y ya no podemos distinguir las huellas del enemigo de las nuestras.

\section{Conclusiones: el mismo destino y la misma piedra}

Más de cien años después de las Guerras indias, cuando los ideólogos neoconservadores pusieron en marcha la Guerra contra el Terror, recurrieron a ideales tan elevados como el del destino manifiesto y tropezaron, como antaño, con la misma piedra: la imposibilidad de evangelizar o convertir al otro si no es reconocido antes como un igual. Una paradoja similar a la que atenazaba el colonialismo cristiano se reduplica en Irak y Afganistán, pues mientras los púlpitos predican sobre sembrar la democracia, se priva de la libertad a un pueblo considerado incapaz de regirse a sí mismo. La misión del evangelio se estrella, una vez más, contra un enemigo concebido como el mal.

A la luz de las palabras de la Constitución (1786) y la Declaración de Independencia (1776), los neoconservadores se arrogaron el deber de propagar por el mundo el ideal de democracia americana y su dogma más revolucionario, que "todos los hombres han sido creados iguales". ${ }^{35}$ Como señalan Franchon y Vernet (2006, p. 26), "desde sus orígenes surgió la idea de un mensaje universal. [...] En ella arraigó el sentimiento de una nación basada en valores universales y predispuso a la creencia en una especie de superioridad americana. América cree con facilidad que encarna el bien". Sin embargo, en contra de su propio dogma neoconservador, George W. Bush estaba retomando al mismo tiempo una retórica centrada en el mal. Según escribía Ceaser (2002), el discurso de Bush "ha dejado a un lado cualquier residuo de la idea ilustrada de que el mal es una fase temporal a superar y ha retornado a la vieja noción del mal como una parte omnipresente de la realidad".

El presidente republicano recuperaba la idea del mal como gangrena sobre la tierra y -en la medida en que éste era visto no como una fiebre pasajera sino como parte orgánica del mundo- la batalla contra él sólo podía conducir a una guerra ilimitada, infinita. No puedo convertirte si te niego el alma, no puedo convencerte si te considero irracional, no puedo liberarte si pienso que tú mismo eres el mal. Ahora y entonces, la oposición al destino manifiesto sólo puede ser consideraba como un acto de maldad irracional o, como diríamos hoy, de terrorismo. Sin embargo, el problema no radica en considerar que haya bandas de apaches desperados o células de Al Qaeda, sino en proyectar la idea del mal sobre naciones enteras: razas contra natura, pueblos enemigos del género humano, religiones terroristas, estados canallas, el Eje del Mal. Como ya sucediera con los indios, la paradoja ofrece al enemigo una misma disyuntiva: o bien puede convertirse en uno de nosotros $-\mathrm{y}$, por tanto, abandonar la condición del mal que lo designa-, o bien debe ser exterminado -pues es el mal y, por tanto, su existencia resulta intolerable-. Massai, el guerrero de Apache, debe aprender a cultivar maíz como los blancos ${ }^{36}$ o morir como guerrero, cosido a balazos; sin embargo, en uno u otro caso, se trata de borrar toda singularidad y toda diferencia en aras de un destino manifiesto: imponer la civilización occidental al resto del planeta.

$$
* * *
$$

Como hemos podido comprobar a lo largo de este artículo, los productos culturales generados en torno a las Guerras Indias y los discursos que ro-

\footnotetext{
${ }_{33}$ Recordemos, por ejemplo, el pionero crucificado en los ademes de la mina que abre el relato de Indian Uprising (Ray Nazarro, 1952), el martirio de Hondo en la novela homónima de Louis L'Amour (2014, p. 169) o, especialmente, el brutal martirio en primer plano del sheriff Hunt (Kurt Russell) en Bone Tomahawk.

${ }^{34}$ GREEN, Adam, 2005.

35 Para la noción de "excepcionalismo americano", véase BARBER, Benjamin, 2004, pp. 92-96 y FISCHER, Joschka, 2006.

${ }^{36}$ Robert Aldrich pretendía un final más trágico para Massai; en cambio, según sus propias palabras, "[Ben] Hetch y la United Artists querían que [Burt] Lancaster pudiera vivir, pero esto convertía en un chiste toda la película" (BISKIND, Peter, 1983, pp. 228-245). Para Peter Biskind, dicho final responde a una de las principales estrategias de control social del Hollywood de los cincuenta: el pluralismo integrador como freno ante la amenaza de la diferencia.
} 
dean la Guerra contra el Terror presentan divergencias, pero también significativos puntos de contacto. En concreto, apreciamos cómo en el presente se recurre a mitos como el destino manifiesto y la cautiva blanca, así como a la deshumanización del enemigo, considerado como fuerza demoníaca e irracional. Si bien algunos de estos rasgos son compartidos por las distintas ideologías imperiales europeas, en el caso estadounidense el discurso en torno al proyecto imperial se trenza indisolublemente con un relato fundacional de importancia crucial: la Conquista del Oeste. Descubrimos así que, si bien no hay una traslación literal de planteamientos, el relato de las Guerras Indias es utilizado por la ideología neoconservadora como un imaginario mítico desde el que escribir la identidad nacional y legitimar su visión de la patria y del enemigo que la acecha.

\section{Bibliografía}

ALTHUSSER, Louis. Lenin and Philosophy and Other Essays. London: New Left Books, 1977.

ASIMOV, Isaac. Los Estados Unidos desde 1816 hasta la Guerra Civil. Madrid: Alianza, 1983.

ASTRE, Georges Albert; HOARAU, Albert-Patrick. El universo del western. Madrid: Fundamentos, 1975.

BALLÓ, Jordi; PÉREZ, Xavier. La semilla inmortal. BarceIona: Anagrama, 1997.

BARBER, Benjamin R. El imperio del miedo: Guerra, terrorismo y democracia. Barcelona: Paidós, 2004.

BARRET, Stephen M. (ed.). Gerónimo. Historia de su vida. Barcelona: Grijalbo, 1975.

BISKIND, Peter. Seeing is Believing. How Hollywood Taught us to Stop Worrying and Love the Fifties. New York: Pantheon Books, 1983.

BROWN, Dee. Enterrad mi corazón en Wounded Knee. Madrid: Turner, 2012.

BROWN, Thomas. "Did the U.S. Army Distribute Smallpox Blankets to Indians? Fabrication and Falsification in Ward Churchill's Genocide Rhetoric". Plagiary: Cross-Disciplinary Studies in Plagiarism, Fabrication, and Falsification, 2006, n. ${ }^{\circ} 1$, pp. 100-129.

CHAMAYOU, Grégoire. Las cazas del hombre. Madrid: Errata Naturae, 2012.

CASAS, Quim. El western: El género americano. Barcelona: Paidós, 1994.

CEASER, James W. "Bush vs. Nietzsche. The politics of evil". The Weekly Standard, 01-4-2002. En: <http:// www.weeklystandard.com/Content/Public/Arti cles/000/000/001/048vhwqw.asp> (Fecha de consulta: 18-01-2016).

CLEMENTE FERNÁNDEZ, Ma Dolores. El héroe del western. América vista por sí misma. Madrid: Ed. Complutense, 2009.

COOPER, James Fenimore. El último mohicano. Madrid: Cátedra, 1997.

CROW, Charles L. American Gothic. Cardiff: University of Wales Press, 2009.

DOVAL, Gregorio. Breve historia de la Conquista del Oeste. Madrid: Nowtilus, 2009.

FALUDI, Susan. La pesadilla terrorista. Miedo y fantasía en Estados Unidos después del 11-S. Barcelona: Anagrama, 2009.
FISCHER, Joschka. El retorno de la historia. Pozuelo de Alarcón: Espasa, 2006.

FONTANA, Josep. Por el bien del imperio: Una historia del mundo desde 1945. Barcelona: Pasado y Presente, 2011.

FRANCHON, Alain; VERNET, Daniel. La América mesiánica. Barcelona: Paidós, 2004.

GALLAGHER, Tag. John Ford: El hombre y su cine. Madrid: Akal, 2009.

GIL CALVO, Enrique. El miedo es el mensaje. Riesgo, incertidumbre y medios de comunicación. Madrid: Alianza, 2003.

GRAY, John. Contra el progreso y otras ilusiones. BarceIona: Paidós, 2004.

GREEN, Adam. "Normalizing Torture in 24" New York Times, 22-05-2005. En: <http://www.nytimes.com/ 2005/05/22/arts/television/normalizing-torture-on24.html> (Fecha de acceso: 15-01-2017).

HÄMÄLÄINEN, Pekka. El imperio comanche. Barcelona: Península, 2011.

HENDERSON, Joseph L. Thresholds of Initiation. Middleton: Wesleyan University Press, 1967.

HOBSBAWM, Eric. Un tiempo de rupturas. Barcelona: Crítica, 2014

JAMESON, Fredric (1988). "Cognitive Mapping". NELSON, Cary; GROSSBERG, Lawrence (eds). Marxism and the Interpretation of Culture. Urbana: University of Illinois Press, 1988.

JEFE JOSEPH. Éramos como el ciervo. Palma de Mallorca: Olañeta Editor, 1998.

L'AMOUR, Louis. Hondo. Madrid: Valdemar, 2014.

LE MAY, Alan. Centauros del desierto. Madrid: Valdemar, 2013.

O'SULLIVAN, John. "Annexation". United States Magazine and Democratic Review, 17, n. ${ }^{\circ}$, julio-agosto de 1845, pp. 5-10. En: <http://web.grinnell.edu/courses/HIS/f01/HIS202-01/Documents/OSullivan.html> (Fecha de consulta: 18-01-2016).

ORTELLS MONTÓN, Elena. Prisioneras de salvajes. Relatos y confesiones de mujeres cautivas de indios norteamericanos. València: Publicacions de la Universitat de València, 2013.

PÉREZ OCHANDO, Luis. "Carne pálida: El mito de la cautiva blanca y su inversión cinematográfica". En: ALBA PAGÁN, E.; PÉREZ OCHANDO, L. (coords.). Me veo, luego existo: Mujeres que representan, mujeres representadas. Madrid: CSIC, 2015, pp. 407-422.

PÉREZ OCHANDO, Luis. Noche sobre américa. Cine de terror después del 11-S. València: Universitat de València, 2017.

ROSENBERG, Carol. "Bitter Analogy in War Crime Case: Indians, al Qaeda". Miami Herald, 23 de marzo de 2011. En: <http://www.miamiherald.com/2011/03/23/ 2130766/war-court-filing-comparing-seminoles. html\#storylink=cpy> (Fecha de consulta: 12-12-2013).

SLOTKIN, Richard. Regeneration through Violence: The Mythology of the American Frontier, 1600-1860. Norman: University of Oklahoma Press, 1973.

TAYLOR, Colin F. (coord.). Los nativos americanos. Madrid: Libsa, 1995.

TIRADO, Michelle. "Military Prosecutors Pull Away from Analogy Likening Seminoles to al Qaeda". Indian Country Today Media Network, 1 de abril de 2011. En: <http://indiancountrytodaymedianetwork.com/20 11/04/01/military-prosecutors-pull-away-analogy-like ning-seminoles-al-qaeda-26135> (Fecha de consulta: 18-01-2016). 
WAYNE, Michael (ed.). Understanding Film: Marxist Perspectives. London: Pluto Press, 2005.

WOOD, Robin. Hollywood from Vietnam to Reagan. New York: Columbia University Press, 1986.
WORCESTER, Donald E. Los apaches: Águilas del Sudoeste. Barcelona: Península, 2013.

ZINN, Howard. La otra historia de los Estados Unidos. Hondarribia: Argitaletxe, 2005. 